\title{
An Analysis of Students' Errors on Storytelling Presentation in English Department, University of Dehasen Bengkulu
}

\author{
Lina Tri Astuty Beru Sembiring \\ Universitas Dehasen Bengkulu \\ Sembiring_11n4@ymail.com
}

\begin{abstract}
This study was aimed to investigate the kinds of grammatical errors made by English Foreign language learners in presenting storytelling. Since the students were learners who came from a multilingual community, the errors they made were affected by the structure of their daily language form. In this study, students were required to produce a story based on the book "Frog where are you" written by Marcel Mayer. This book contains 29 pictures which tell a story without any texts on it. The writer then audiotaped students' storytelling and then made a transcription. The storytelling presentations of 5 students of English Departement of Universitas Dehasen Bengkulu were investigated by using the surface structure taxonomy of errors namely, misformation, misordering, addition, and omission. Findings indicated that omission was the highest kind of errors accounted on the total grammatical errors made by the students. It then followed by misformation, addition and also misordering.
\end{abstract}

\section{ARTICLE HISTORY \\ Received 15 April 2017 \\ Accepted17 August2017}

\section{KEYWORDS}

Language Acquisition; Error analysis; storytelling presentation

\section{Introduction}

The globalization era has forced people from different areas, cultures, and languages to communicate with each other. In order to facilitate this process, people need to master some new languages as their second or foreign language in order to manage the interaction In many Asian countries including Indonesia, mastering a new language has become a norm in their daily (Ellis, Rod:999)

There are several ways existed to help learners in acquiring a new language whether it is as their second or foreign language. Klein (1986) differentiated the process as a spontaneous and guided acquisition. In spontaneous acquisition, learners are focused on naturalistic language acquisition in which they learn the language incidentally. In another hand, the learner is in instructed language acquisition when their learning is focused on some aspect of the language system. Based on the different focuses of these two ways of acquiring a new language, a different kind of problems also occur including an error they made in producing the language. In this writing, the writer focuses her research on the errors produced by the learner in instructed second language acquisition.

Every second or foreign language learner must have made an error in 
producing or comprehending new sentences. As these errors are generally viewed as unwanted forms in the process of language learning, many studies have been conducted in investigating and solving the problem. In the 1970s, the work of Error Analysis (EA) had been started by Corder (1981). He started the procedures by collecting samples of learners language, identifying the error they have made, describing the errors, classifying them based on their nature and causes and finally evaluating their seriousness. These procedures help teacher and researcher in providing a complete methodology for investigating learner's language. They also constitute an appropriate starting point for studying the language uses. In short, a study through EA is very significant in three ways. First, It provides teachers with information about how much the learner had learned. Second, It helps them with evidence of how language is learned, and third, it serves as devices by which the learner discovered the rules of the target language.

Another alternative to study errors is by using a surface strategy taxonomy proposed by Dulay, Burt, and Crashen (1982). They have highlighted the languages' errors using Omissions, additions, misinformation and also misorderings. Omission errors are characterized by the absence of an item that must be there in a well-formed utterance such as grammatical and content morphemes. While also, learners usually add an item that should not appear in a well-formed utterance. These errors usually occur in the later stages of foreign language learning when learners learn some rules of the new language. They are subclassified into three types, double marking, regularization, and simple addition. Misformation as the third category is characterized by the use of the wrong form of the morpheme or structure,i.e.applying some part of the rule and leaving the other. The last category is Misordering. This error characterized by the incorrect placement of a morpheme or group of morphemes in an utterance. Using the taxonomy of errors can help people to see that many language learners are omitting necessary items or adding unnecessary ones; they may misform items or disorder them. In short, it can be said that structure taxonomy of errors gives a clear description of learners' cognitive processes that underlie their reconstruction of the new language or language being learned.

There were many studies have been conducted in investigating students' error. Each of them has been studied through different perspectives. In this article, the writer will review some of them to add new knowledge and information on students' kind of errors. Reza Kafipour \&Laleh Khojasteh conducted the first study, in 2012 entitled A comparative taxonomy of errors made by Iranian Undergraduate learners of English. This article was published in Canadian Social Science Journal, Vol.8 No.1,2012, 18-24. In this study, the writers investigated the errors made by Persian learners in writing an English essay. They categorised students' writing errors based on the comparative taxonomy which divided students'errors based on its sources; interlingual, developmental, ambiguous dan others sources. In this study, 40 Persian learners of English at Shira Abad University were taken as samples. They were 
selected based on their Grade point Average. The study found that the majority of errors made by students were from developmental sources. It is kind of error which has similarities with an error made by children in learning their first language. The second kind of errors found in students' writing is Ambiguous errors. This error reflects the learners' native language structure. This type of error usually found in the speech of children in acquiring their first language. The lowest type of errors found in students writing is interlingual errors in which students make their English writing semantically equivalent with their native language. In identifying this kind of errors, the writers usually translate the grammatical form of their sentence into students native language. The similarities found in it showed that the errors reflected students' native language structures.

The second study was conducted by Khansir, A in 2012 through his articles entitled Error Analysis and second language Acquisition. In this article, he examines the three most influential theories in error analysis; Contrastive Analysis, Error Analysis, and interlanguage theory. He has described that between this three analysis on the error, error Analysis is the type of linguistics analysis that focused on the error made by learners. It also compares between the errors' students made with their native and target languages. This kind of errors has been classified into three specification, overgeneralization, Ignorance of rule restriction, incomplete application of rules, and false concepts hypothesised (Richards,1971, in Akbar,2012).

In the English Department of Universitas Dehasen Bengkulu, many students get difficulties in producing well-structured languages, especially in oral presentation. Most of them also have a lack of communication skill. In this research, the writer is interested in investigating the kind of errors that students produce in a spoken text. A transcribe of Students' storytelling presentation then become the data of this research. The research was conducted on Mei to June 2015 at fourth-semester students of English Department of Universitas Dehasen Bengkulu. It was experimental research which aimed to investigate students' errors in using English as a foreign language through storytelling presentation. Students were required to produce a story based on the book "Frog where are you" written by Marcel Mayer. This book contains 29 pictures without any text on it. Students were asked to make a story based on those pictures. The writer then audiotaped students' storytelling and then made a transcription. The transcription then was analyzed by using a surface taxonomy of error which divided students' errors into four types: omission, addition, misformation and misordering.

\section{Result and Discussion}

This section presents the result of students errors in presenting a storytelling. These errors were categorized based on the structure taxonomy of errors suggested 
by Dulay, Burt, and Krashen in 1982. They are including Omission, addition, misformation and misordering. From the result, it was known that Misformation (52.6\%) was the most frequent category of error made by students of Universitas Dehasen Bengkulu. It was followed by Omission (27.6\%), addition (11.9\%) and also Misordering (7.9\%).

Table 1. Percentage of Students errors

\begin{tabular}{llll}
\hline No & Types of Error & Total & Percentage \\
\hline 1. & Omission & 42 & 27.6 \\
\hline 2. & Addition & 18 & 11.9 \\
\hline 3. & Misformation & 80 & 52.6 \\
\hline 4. & Misordering & 12 & 7.9 \\
\hline & & $\mathbf{1 5 2}$ & $\mathbf{1 0 0}$ \\
\hline
\end{tabular}

Based on the table, it was known that Misformation was the most significant errors done by students. Most of them got difficulties in producing an appropriate form of the morpheme or structure. It was caused by the differences in the rules of word formation between the students' native language and the target language that they used. As it is defined that Misformation is characterized by the use of the wrong form of the morpheme or structure (Dulay, Burt and Krashen,1982). The following are examples taken from students storytelling :

\section{Misformation 1.}

he is sleep with his dog $=$ He is sleeping with his dog

The speaker in this sentence intended to inform the reader that the boy in the story is sleeping with his dog. When we looked at the sentence, we know that the verb sleep must be in the form of present participle and the speaker needs to change the verb form into ING-form.

\section{Misformation 2.}

he try to find his frog anywhere $=$ He tries to find his frog everywhere

Still, with the same problem, the student in this sentence use the wrong form of a verb. He tells people about a present action. Thus the verb try must be in the form of present tense (base form+s). Another error was in the use of word anywhere. This word is usually used for the negative statement. This word can be best replaced by the word everywhere which is definitive and be more appropriate for a positive statement.

\section{Misformation 3}

a boy climb the trees $=$ the boy climbs the tree

In this sentence, the speaker used a wrong article to mention a specific object which the listener had already known. It is best to change the article ' $a$ ' in the word "a boy" into article 'the' referring to the boy who was involved in the story. Another 
problem is also found in the form of the sentence. Because there is only one boy in the story, so the verb 'climb' must be changed into the present form 'Climbs.'

Anothererroris related to the term Omission. It is considered to be the second type of errors produced by students. It happens when there is an absence of item that should appear in a well-formed utterance. Here are the samples of omission produced by students in storytelling presentation.

\section{Omission 1}

the frog*trying to come out from the bushes= the frog is trying to come out from the bushes

In this remark, the speaker tried to tell the listener that the frog is trying to come out from the bushes. That he needs to add tobe is before the present participle thus this sentence become in progressive which describe actions already in progress at the moment "in focus" within the sentence

\section{Omission 2}

$i$ want to tell $*$ about the pictures in the book $=I$ want to tell you about the pictures in the book

In the example, the speaker has ommited the object you. This object is needed to complete the sentence therefore it can be a complete sentence.

\section{Omission 3}

The little boy *very handsome $=$ The little boy is very handsome

The speaker wanted to give a description to the listener about the little boy appearance in the story. He wanted to say that the boy in the story is good looking. For this purpose, the speaker needs to put be (is) to complete the sentence.

The Error of Addition is the third kind of error found in students story telling presentation. This kind of error can be identified by looking at word or phrase that contains unnecessary addition. Below are the examples:

\section{Addition 1}

From behind the big stone suddenly come up a big deer.

On that sentence, the speaker used two prepositions before the subject. This thing can happen because the speaker was not sure which preposition is suitable to be used before the subject.

\section{Addition 2}

I think they want to be play together

The speaker of this sentence put unrequired 'be' before the word play. It seems that he wants to make a passive infinitive thus this sentence become incorrect then.

\section{Addition 3}

the everychildren feel very happy

In this sentence, the student uses the wrong articles on his sentences. Actually, when he want to use article "the" in this sentence, he does not need to add the word every after it. By using these two altogether, he has made a wrong sentence. 


\section{Misordering}

He sees a black, big,beautiful bird is singing on the tree

In this sentence, the student makes a mistake when trying to describe the noun Bird. When using multiple adjectives in a sequence, he must be aware of the use of the correct adjectives order. The proper order of adjective should be as follows: determiner, observation, size, shape, age, color, origin, material, qualifier. So this sentence best replaced by " They see a beautiful, bigblack bird is singing on the tree."

\section{Discussion}

Using structure taxonomy for classifying students' errors can give us an understanding of the cognitive process of learners in acquiring a new language. The research conducted in the English Department of Universitas Dehasen Bengkulu found that between four kinds of errors, misformation was the highest type of errors made by students. It then followed by omission, addition and also misordering.

According to Dulay, Burt, and Krashen,1982, Misformation of errors characterized by the use of a wrong form of the morpheme or structure. There are three types of misformation errors: regularization, archi-form and also alternating forms. (a) In regularizations, an irregular markeris replaced by a regular one, as in * sheeps for sheep. (b) Archi-forms refer to the use of onemember of a class of forms instead of using all the members, e.g., using this in the situations wheneither this or these should be used. (c) Alternating forms are represented by "free alternation ofvarious members of a class with each other", as in *those dog and this cat used by the same learner(Dulay et al. (1982: 157). In the Misformation errors made by English department students of Universitas Dehasen Bengkulu, we can easily found that the students do all the three types of misformation errors especially in the form of regularizations. According to Smithies and Holzknecht's there is no reason why this kind of errors can exist.

An omission is a type of error which is characterized by the absence of an item that must appear in a well-formed utterance (Dulay and Burt,1982). As we know that morphemes or words are divided into lexical and grammatical morphemes. Lexical morphemes or Content words is words that have meaning by themselves. It consists of nouns, verbs, adjectives and also adverbs that have referential meanings. Inanother hand, grammatical morphemes or function words are those words that function to specify the relationship between one lexical morpheme with another. Based on the finding, the errors made by students of the English department of Universitas Dehasen Bengkulu was mostly found in the form of grammatical morphemes. They include noun and verb inflection (-es, ed, ing), the article (athe, an), Verb auxiliaries (is, will, can, may), and preposition (in, on,at). 
Error, in addition, is in the third places. An addition is a type of errors which are characterized by the presence of an item which must not appear in a well-formed utterance(Dulay, Burt and Krashen,1982). There are three types of addition errors: double markings, regularization, and simple addition. Double marking often occurs due to the failure to delete individual items which are needed in some linguistics constructions. While the regularization is a type of errors in which a marker that is typically added to an exact item is erroneously added to exceptional items of the given class that do not take a marker. The last category is simple addition which refers to all addition errors (Dulay,Burt and Krashen,1982). For students of English Department of Dehasen University, these three types of error on addition occurred.

The last type of error is misordering which occurs because there is a group of morphemes or a morpheme that placed incorrectly. In the case of students of Universitas Dehasen Bengkulu, students translated every single word of native language surface structures into the target language. Corder and Krashen in 1982, stated that this type of error occurs when Students have made written misordering errors that are influenced by word for word translation of native language surface structures.

\section{Conclusion}

This study has examined errors in the storytelling presentation of English Department Students of Dehasen University by using the structure taxonomy of errors. There are four kinds of basic taxonomy of errors made by fourth-semester students of English Department of Universitas Dehasen Bengkulu. They are misformation, omission, addition and also misordering. Misformation was the highest kind of errors made by students consisted of $52.6 \%$ of the total errors. It then followed by omission errors (27.6\%), an addition of errors (11.9\%) and also misordering $(7.9 \%)$. Classifying errors using surface structure taxonomy can give us a clear description of cognitive processes that underlie the learners' reconstruction of a new language or language being learned. It also makes us aware that learners' errors are the result of their active way of using some principles to pronounce a target language. It is then hoped that Knowledge on learners' Errors can provide the picture on linguistic development of them and also can produce suitable teaching materials in improving students' language acquisition and performance.

\section{References}

Corder, S.P. (1981).Errors Analysis and Interlanguage. Oxford:Oxford University Press.

Dulay,H.,Burt.M \& Krashen,S.(1982). Language two. New York: Oxford University Press. 
19 | VISION: JOURNAL FOR LANGUAGE AND FOREIGN LANGUAGE LEARNING

Ellis,rod.(1999).Second Language Acquisition.Oxford:Oxford University Press.

Kafipor,Reza.\&Lalehkhojasteh.(2012). A comparative taxonomy of errors made by Iranian Undergraduate learners of English. Canadian Social Science Journal, Vol.8 No.1,2012, 18-24

Khansir,A.(2012). Error Analysis and Second Language Acquisition. Theory and Practice in Language Studies,Vol.2,No.5,pp 1027-1032

Mohamad Ainon Jariah.\&Mohamed Ismail. (2013). Oral Presentation errors of Malaysian Students in an English for Academic purposes (EAP) Course. World Applied Sciences Journal Vol 21, 2013,19-27

Muhamad et.al. (2013). Oral Presentation errors of Malaysian Students in An English for Academic Purposes (EAP) Course. World Applied Sciences Journal 21,19-27 